\title{
STUDY OF CONTRACT OBJECT IN MULTI-SERVICE FINANCING USING IJARAH IN ISLAMIC BANK*
}

\author{
Kamalia Firdausi \\ Magister Hukum, Universitas Muhammadiyah Yogyakarta, \\ Jl. Brawijaya, Kasihan, Bantul, D.I. Yogyakarta 55183 \\ e-mail: firdausikamalia@gmail.com
}

\begin{abstract}
In a case of a dispute between an islamic bank and a customer related to multi-service financing using an ijarah contract at an islamic bank, the customer is suing for the cancellation of the contract on the multi-service financing on the grounds that the object of the contract is not the object of the contract, so the contract should be null and void. However, the court decision stated that he rejected the customer's claim. This research was conducted to examine the application of sharia principles in legal considerations in court decisions regarding contract objects in multiservice financing using the ijarah contract. This research is a normative legal research using the statutory approach method. The results of this study indicate that the legal considerations in court decisions regarding the object of the contract in multi-service financing using the ijarah contract are formally correct, but materially there is still a possibility of gharar that is not in accordance with sharia principles.
\end{abstract}

Keywords: Ijarah; Multi-service Financing: The Object of The Contract.

\begin{abstract}
Abstrak
Dalam sebuah kasus sengketa antara bank syariah dengan nasabah terkait pembiayaan multijasa yang menggunakan akad ijarah di bank syariah, nasabah menggugat pembatalan akad atas pembiayaan multijasa tersebut dengan alasan objek akad bukan merupakan objek akad, sehingga seharusnya akad tersebut batal demi hukum. Namun, putusan pengadilan menyatakan menolak gugatan dari nasabah tersebut. Penelitian ini dilakukan untuk mengkaji penerapan prinsip syariah dalam pertimbangan hukum pada putusan pengadilan tentang objek akad dalam pembiayaan multijasa yang menggunakan akad ijarah. Penelitian ini merupakan penelitian hukum normatif dengan menggunakan metode pendekatan perundang-undangan. Hasil penelitian ini menunjukkan bahwa pertimbangan hukum dalam putusan pengadilan terkait objek akad dalam pembiayaan multijasa yang menggunakan akad ijarah sudah benar secara formil, namun secara materiil masih ada kemungkinan terjadi gharar yang tidak sesuai dengan prinsip syariah.
\end{abstract}

Kata Kunci: Ijarah; Objek Akad; Pembiayaan Multijasa.

\footnotetext{
* Naskah diterima: 30 November 2020, direvisi: 4 Maret 2021, disetujui untuk terbit: 25 Maret 2021

Doi: 10.3376/jch.v6i2.316
} 


\section{INTRODUCTION}

Islamic bank products in the form of financing are one of the most widely used products by the public. Most of the Islamic bank financing products distributed to the public are still dominated by two contracts: the murabahah and musyarakah contracts. Throughout 2017 alone, the dominance of financing with a murabahah agreement reached $53.23 \%$, while for financing with a musyarakah agreement it reached $34.87 \%$ (Otoritas Jasa Keuangan et al., 2017). Even though in addition to financing with a murabahah contract and a musyarakah contract, there are many more Islamic banking financing products that can be done in Islamic banks, one of which is multi-service financing with an ijarah agreement.

Multi-service financing is known in Islamic banking practice as financing carried out to obtain benefits for goods or services. Multi-service financing can be carried out in two ways, namely by using the ijarah contract principles and the kafalah contract. In this paper, we will discuss more about multi-service financing using an ijarah contract. Multiservice financing with an ijarah contract means financing in an Islamic bank to obtain benefits for a good or service using the principles contained in the ijarah contract. Ijarah contracts in Islamic banks can be used for rental transactions of goods or use of services (Purwanto, 2017). Ijarah contract is a lease agreement between the lessor and the lessee to exchange benefits and wages for a good or service.

In a case between an Islamic financing bank (hereinafter referred to as Islamic bank) and its Customer (hereinafter referred to as the Customer) there is a dispute relating to multi-service financing using an ijarah contract. Whereas between the Islamic bank and the Customer there has been a multiservice financing using an ijarah contract with the object of the contract in the form of benefits from a rented shop.

To describe what happens in multiservice financing, it is necessary to know that in the financing contract there are two contracts, namely the wakalah contract and the ijarah contract. Islamic bank authorizes the Customer to rent a shop using a wakalah contract. After the Customer rents a shop on behalf of an Islamic bank based on the wakalah contract, in principle, the Islamic bank has become the party controlling the object by becoming a shop tenant. Then the benefits from the shop that has been rented on behalf of the Islamic bank are what is given and leased to the Customer to be used or utilized as the object of the contract. Only after that the ijarah contract between the Islamic bank and the Customer was born.

That the Islamic bank as the party providing financing also acts as the party that bears the risk. Therefore, to ensure that the Customer is willing to pay the financing installments, the Islamic bank asks the Customer for a guarantee in the form of a Property Right Certificate 
Kamalia Firdausi: Study Of Contract Object In Multi-Service Financing Using Ijarah In...

(hereinafter referred to as the collateral object). The collateral object is then charged the Mortgage. The Islamic bank and the Customer have signed a Power of Attorney to Charge Mortgage Rights (in Indonesia called SKMHT), until the issuance of the Certificate of Encumbrance (in Indonesia called APHT) as well as the imposition of Mortgage Rights on the collateral object and it has been recorded in the Land Book at the Land Office, so that the Rights Certificate is issued on the collateral object.

However, in the course of the contract, the Customer's business went bankrupt, resulting in delinquency in installment payments by the Customer to the Islamic bank. The Customer has committed a default in which he cannot continue the monthly installment payment, so the Islamic bank has arrived at a decision to auction off the collateral object.

Disputes between Islamic bank and Customers do not stop there. The Customer then submits a lawsuit to the court against the Islamic bank. The lawsuit filed is to declare the multiservice financing with the ijarah agreement between the plaintiff (Customer) and the defendant (Islamic bank) is null and void. The reason for the plaintiff's submission of the lawsuit is that it relates to the objects that are the object of the multi-service ijarah contract. According to the plaintiff, objects that become objects in the multi-service financing contract cannot be called the object of ijarah, so the contract should be null and void. However, the court ruling stated that he rejected the lawsuit. Based on this background, the authors are interested in examining whether the legal considerations in decisions about contract objects in multi-service financing using ijarah contracts in Islamic bank are in accordance with sharia principles.

\section{RESEARCH METHODS}

This type of research is normative legal research. "Normative legal research is legal research that places law as a norm system building" (Fajar ND \& Achmad, 2010). The norm system is used as literature that can be in the form of principles, norms, rules of legislation, fatwas, court decisions, agreements, as well as doctrines or teachings. The approach method used is the statutory approach method in which various legal rules are placed as the focus of the research. In this case, the author examines various legal rules related to multi-service financing and ijarah contracts as the focus of research. This study was analyzed using descriptive methods. Descriptive method is a method that is carried out by compiling legal materials obtained coherently or systematically and logically to get a clear picture or description of the problem formulation.

\section{RESULTS AND DISCUSSION Ijarah Contract}

Akad is a term in Islamic law that is used to refer to an agreement. "An agreement is an event that occurs when the parties promise each other to carry out certain actions" (Ardi, 2016). The particular action in question is to give 
something, do something or not do something which is better known as achievement (Nikmah et al., 2020).

A contract is the meeting of ijab and kabul as a statement of will between two or more parties resulting in legal consequences on a certain object. There are at least three elements that can be described from the meaning of the contract. First, the contract is a meeting of ijab and kabul which has legal consequences. Second, the contract is a legal action between two or more parties because the contract brings together ijab as a representation of the other party's will and kabul as a statement of the will of the other party. Third, the contract as an action that aims to cause legal consequences (Anwar, 2007).

Ijarah comes from the word al-ajru which means to change (Febrianasari, 2020). According to syara', the meaning of ijarah is a contract to take advantage by replacing it (Lazwardi, 2018). Ijarah is one type of contract that benefits through replacement, in other words, ijarah is a transaction to sell benefits (Salim HS \& Muhaimin, 2018). Therefore, ijarah is included in the category of sale and purchase contracts (Syauqoti \& Ghozali, 2018). However, what distinguishes it from the principle of a sale and purchase contract in general is in terms of the object (Pratiwi \& Rifa'i, 2017). In the sale and purchase agreement the object is the goods, while in the ijarah the object is the benefit of the goods or services (Solihah, 2014).
The legal basis for ijarah can be seen in Surah Al-Baqarah verse 233, "... and if you want to feed your child to someone else, then there is no sin for you to pay in a proper way. Fear Allah and know that Allah is All-Seeing what you are doing. "

In that verse there is expression "to pay in an appropriate manner", which indicates a payment of wages for services rendered (Antonio, 2001). In essence, ijarah is a transaction or service contract with a compensation because in ijarah there is a reciprocal relationship between people who take benefit from someone services by providing wages or compensation for the services he has provided (an Nabhani, 2009).

Apart from the Quran, the legal basis for ijarah can also be found in the Hadith. As the Hadith History of Bukhari No. 2119 which reads, "Has told us Abu Nu'aim has told us the Mis'ar of 'Amru bin' Amir said: I heard Anas radiallahu 'Anhu say: The Prophet salallahu' alaihi wasallam had a grip and he never wronged anyone's wages".

Hadith History of Ibn Majah No. 2155, "Having told us Abdul Hamid bin Bayan Al Wasithi said, told us Khalid bin Abdullah from Yunus from Ibn Sirin from Anas bin Malik said: Prophet salallahu 'alaihi wasallam did cupping and rewarded the cupping maker".

In Indonesia's positive law, the term ijarah is mentioned in Law Number 21 of 2008 concerning Islamic Banking (hereinafter referred to as the Islamic Banking Law). Precisely in the 
Kamalia Firdausi: Study Of Contract Object In Multi-Service Financing Using Ijarah In...

Elucidation of Article 19 letter $\mathrm{f}$ of the Islamic Banking Law. In addition, the National Sharia Council of the Indonesian Ulama Council has also issued Fatwa Number 9/DSN-MUI/IV/2000 concerning Ijarah Financing and Fatwa Number 112/DSN-MUI/IX/2017 concerning the Ijarah Akad which is the legal basis for the implementation of ijarah in Indonesia.

According to Islamic Banking Law, ijarah is a "contract to provide funds in order to transfer the use rights or benefits of a good or service based on a lease transaction without being followed by a transfer of ownership of the goods themselves". According to the Fatwa of the-National Sharia Council of the Indonesian Ulema Council (DSN-MUI) Number 9/DSN-MUI/IV/2000 concerning Ijarah Financing, ijarah is a "contract of transfer of use rights (benefits) over an item within a certain time with rental payments (ujrah), without followed by transfer of ownership of the goods themselves".

Like the contract in general, ijarah also has pillars and conditions. There are three pillars and conditions for ijarah, namely (Ijarah Financing, 2000):

1. Sighat ijarah, namely statements from both parties who act, either verbally or in other forms.

2. Contracted parties consisting of lessees or service providers and lessees or service users.

3. The objects of the ijarah contract are goods benefits and rent or service benefits and wages.
Ijarah can only be carried out if these pillars and conditions have been met. Like the contracts in general, if these conditions are not met, it can be canceled or the ijarah is considered null and void (Insawan, 2017).

According to scholars, the ijarah contract is divided into two types based on its object, namely (Al Hadi, 2017):

1. Ijarah is beneficial, namely ijarah whose object is in the form of objects or goods and must have benefits. Examples are ijarah to houses, clothes, vehicles and so on.

2. Ijarah is work, which is ijarah that occurs because someone employs another person to do a job. An example is someone who asked a tailor to sew a cloth into a shirt. The person who sews the clothes will get wages from the sewing work he does. This type of Ijarah is allowed as long as the work is clear and does not contain an element of fraud.

\section{Multi-service Financing}

The National Sharia Council of the Indonesian Ulema Council (DSN-MUI) sees an opportunity from the growing needs of the community, so that Islamic financial institutions need to respond to the needs of the growing community (Hayati, 2014). Through Fatwa Number 44DSN-MUI/VIII/2004,

DSN-MUI stipulates provisions on multi-service financing.

Multi-service financing is financing to obtain benefits for a service. Islamic Banks provide Multi-service financing to 
customers by providing benefits for a service (Nurkamilah et al., 2016). Multiservice financing practices are legally permissible. Multi-service financing can be done using an ijarah contract or a kafalah contract.

Multi-service financing using both of the ijarah contract or the kafalah contract cannot be automatically applied to various customer needs. This is because multiservice financing must be carried out in accordance with the fatwa of each contract used (Syakur, 2010). If multiservice financing is carried out using an ijarah agreement, the fatwa's provisions regarding ijarah will apply. Likewise, if multi-service financing is carried out by means of a kafalah contract, the provisions in the fatwa regarding the kafalah contract will apply.

Multi-service financing that uses an ijarah contract is financing aimed at customers who need funds quickly to meet their needs by requiring the provision of ujrah in each installment paid by the customer to Islamic banks (Khasanah \& Mustaqim, 2020). Ujrah must have been agreed upon in advance by the parties and must be stated in nominal terms. The object of financing in multi-service financing using an ijarah contract is in the form of benefits for a service.

Multi-service financing with an ijarah contract is a development of the concept of benefits which is the object of ijarah. Suppose previously the ijarah contract was carried out for goods or services that were simple in nature. In that case, the multi-service financing contains many services that are used as the object of the ijarah contract (Rahayu \& Nurhasanah, 2020). Multi-service financing using an ijarah contract must be carried out with due observance of the Fatwa of the National Sharia Council of the Indonesian Ulema Council Number 9/DSN-MUI/IV/2000 concerning Ijarah Financing. The provisions for multiservice financing objects that use an ijarah contract include the following (Ijarah Financing, 2000):

1. Objects in the form of benefits for a service;

2. Benefits of a service must be assessable and can be implemented in the contract;

3. Benefits of a service must be permitted (not haram);

4. Disturbance in fulfilling benefits must be real and in accordance with the rules;

5. Benefits must be identified specifically in such a way as to avoid ignorance which will lead to disputes;

6. The specification of benefits must be clearly stated, including the time period and physical identification;

7. Rent or wages are what customers promise and pay to Islamic banks as benefit payments. What can be used as a price in buying and selling can also be used as rent or wages;

8. Payment of rent or wages is allowed in the form of services of the same type as the object of the contract; 
Kamalia Firdausi: Study Of Contract Object In Multi-Service Financing Using Ijarah In...

9. Flexibility in determining rent or wages can be expressed in terms of time, place, and distance.

The Object of the Contract in MultiService Financing Using Ijarah at an Islamic Bank According to Sharia Principles

Multi-service financing using an ijarah contract must follow the provisions in the Fatwa concerning Ijarah (Multiservice Financing, 2004). Therefore, in the implementation of multi-service financing using the ijarah agreement, refer to Fatwa Number 9/DSNMUI/IV/2000 concerning Ijarah

Financing and Fatwa Number 112/DSNMUI/IX/2017 concerning Ijarah Akad. According to Fatwa Number 9/DSNMUI/IV/2000 concerning Ijarah Financing, the object of the contract is the benefit from the use of goods and or services. In multi-service financing, the object of the contract is the benefits of using the service.

According to Fatwa Number 112/DSN-MUI/IX/2017 concerning Akad Ijarah, multi-service financing using the ijarah contract is included in the ijarah 'Ala al-a'mal, which is a lease agreement for services or people's work. In ijarah 'Ala al-a'mal the term Ajir is known, namely the party providing services. The party that is domiciled as an Ajir in multiservice financing is a Islamic bank. Whereas the object in the ijarah contract is better known as the benefit or manfa'ah because basically in the ijarah contract what is transacted is the benefit of a good or service.
In the ijarah contract, there is no transfer of ownership because there is no transfer of ownership rights, but what is given is the benefits of the ownership rights. If what is the right of ownership is in the form of an item, then what is submitted is the benefit of the item.

Benefits as objects in the ijarah contract must meet several conditions. Are as follows (Ijarah Contract, 2017):

1. Benefits are benefits that are justified or not prohibited by sharia;

2. Benefits must be clear and known to the lessor and the lessee or service provider;

3. The use of benefits and the period of use must be determined and agreed upon by the parties;

4. The lessee can lease the benefits back to another party unless lessor does not permit it;

5. The lessee is not obliged to bear the risk of loss arising from the use of benefits unless there is a default.

According to muamalah fiqh, the object of ijarah is something that can be submitted and used and there are no defects in it. The jurisprudence scholars agree that it is not permissible for an object to be leased to be something that cannot be surrendered, to be used directly by the tenant (Hasan, 2018).

In muamalah fiqh it is also explained that everything related to property can be used as the object of ijarah, but these assets must meet several requirements first. These requirements are as follows (Hasan, 2018): 
1. Assets in the ijarah must be able to be used directly and the assets must not have defects that can affect their function and must not be allowed if the assets being transferred are still under the control of another party, namely not the two parties who have contracted;

2. The quality and quantity of benefits of property must be conveyed transparantly without being hidden by the owner;

3. Property which is used as the object of ijarah must be in the form of real property, namely property that can be used repeatedly without causing damage to the substance and its nature management;

4. The benefits of the object of ijarah do not conflict with Islamic law;

5. The object is leased directly from an object;

In multi-service financing, the benefits provided are the benefits arising from a service. Services carried out in multi-service financing with an ijarah contract must be in the form of work permitted by sharia, means that the work is not a job prohibited by sharia. The type of work done must also have clear specifications and sizes and it must also be clear how long it will take to do the work. Services or work performed must also be in accordance with the objectives of the contract (Ijarah Contract, 2017).

The features and mechanisms for multi-service financing with an ijarah contract are as follows (Otoritas Jasa Keuangan, 2015):
1. Islamic bank act as providers of funds in multi-service financing activities using ijarah contracts with Customers.

2. Islamic bank are required to provide funds to realize the provision of rental objects ordered by Customers.

3. Refunds for provision of funds from Islamic bank to Customers cannot be made in the form of receivables.

In practice in Islamic bank, ijarah contracts are carried out in financing that involves various services. Islamic bank provide financing to Customers for a service using an ijarah contract, so it is called a multi-service financing with an ijarah contract. In general, the stages of implementing ijarah based on the standard operational procedure (SOP) submitted by Islamic bank are as follows:

1. There is a request to rent certain goods with clear specifications by the Customer to Islamic bank;

2. Promises between Islamic bank and Customers to rent goods at an agreed rental price and period;

3. Islamic bank look for the goods the Customer wants to rent;

4. Islamic bank lease the goods from the owner of the goods;

5. Islamic bank pay the lease in advance in full;

6. Goods are handed over from the owner of the goods to Islamic bank;

7. The contract between the Islamic bank and the Customer for lease;

8. The Customer pays the lease to the Islamic bank in installments; 
Kamalia Firdausi: Study Of Contract Object In Multi-Service Financing Using Ijarah In...

9. Goods are handed over from the Islamic bank to the Customer;

10. After the end of the period, the goods are handed back from the Customer to the Islamic bank and from the Islamic bank to the owner of the goods (Sudiarti, 2018).

Based on the stages of implementing the ijarah above, Islamic bank lease an asset and lease it back to the Customer, then the Customer will rent the asset in installments. Apart from the same as the stages of the implementation of the ijarah, multi-service financing can also be carried out like murabaha. Islamic bank can represent Customers to lease assets or services that Customers want on behalf of Islamic bank. Furthermore, the Islamic bank leases it back to the Customer at a price difference from the initial price (Mubarok \& Hasanudin, 2017).

It is important to remember that the benefits as objects in the ijarah contract must first belong to the Islamic bank before they are made the object of the contract and later handed over to the Customer. Islamic bank cannot immediately enter into direct contracts with Customers without doing one of two things as follows:

1. Islamic bank buy these benefits from third parties (goods owners) through a cooperation agreement; or

2. Islamic bank authorize Customers to purchase benefits from third parties using a wakalah contract (Mubarok \& Hasanudin, 2017).
In a case as mentioned in the introduction, the practice of multi-service financing using an ijarah contract is carried out by the Islamic bank to the Customer. Islamic bank provides and provides services to customers in the form of financing to pay for the cost of renting a shop (Multi-service Financing, 2004). The bank entrusts an amount of money to the customer so that the customer can pay it for the cost of renting a shop on behalf of a Islamic bank, so that a wakalah contract also accompanies this financing. After the shop has been rented under an Islamic bank's name, the Islamic bank can make an ijarah contract with the customer (Wakalah Transaction Contract, 2016).

Islamic banks provide and provide services called benefit leasing services in the form of money to Customers. The transfer of money is carried out simultaneously with the implementation of the ijarah contract between the Islamic bank and the Customer. For services performed by Islamic bank, Islamic bank and Customers agree on the amount of ujrah to be received by Islamic bank, which in the contract is referred to as benefit lease costs (Multi-service Financing Contract, 2016).

In this financing, it was agreed that the payment for the benefit lease service and benefit lease fee from the Customer to the bank shall be made in installments. The Customer promises to pay in installments to the Islamic bank during the agreed period, namely 60 months from the signing of the contract. 
From the previous explanation, a multi-service financing scheme with an ijarah contract between Islamic banks and customers if described will look like the following figure.

Picture 1.

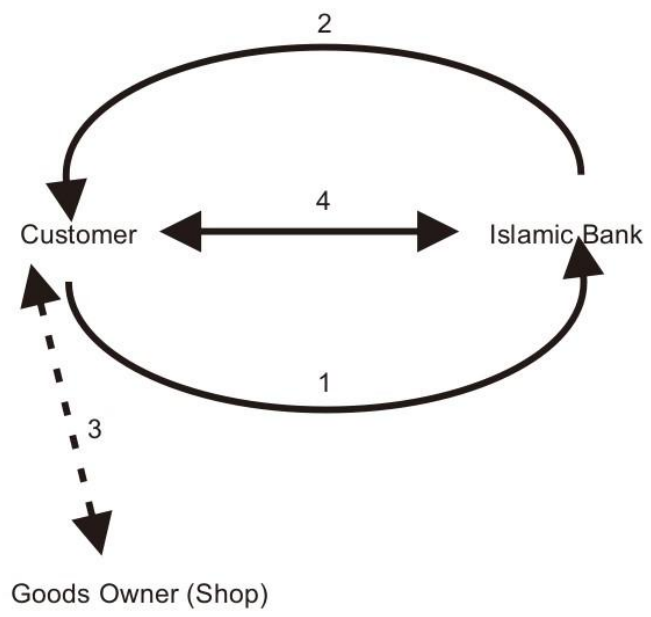

Multi-service Financing Scheme that uses an Ijarah Contract between the Islamic Bank and the Customer.

Information:

1. The customer applies for financing to a Islamic bank in order to provide services and submit a lease of benefits for the service to the customer for store rental costs.

2. The bank approves the customer's request and provides services and submits a lease of benefits for the service to the customer in the form of an amount to pay for the shop rental fee. In this case, the Islamic bank authorizes the customer to pay the money to the shop owner who will be rented on behalf of the Islamic bank based on the wakalah contract.
3. The customer pays the shop rental fee to the owner of the goods on behalf of and on behalf of the Islamic bank and then the owner of the goods hands over the rented shop's benefits.

4. After the shop rented benefits have been controlled by the Islamic bank, the Islamic bank and the customer enter into an ijarah contract for the benefit leasing services performed by the Islamic bank. For the services performed by these Islamic banks, the customer gives ujrah to Islamic banks.

Based on this scheme, in multiservice financing between a Islamic bank and a customer, there are two contracts, namely the ijarah contract and the wakalah contract. The ijarah contract is the main contract in financing while the wakalah contract is the supporting contract. A wakalah contract is a transaction from one party to another to do something on its behalf (Latifah \& Fariskasari, 2020).

Ijarah contracts are carried out by Islamic bank with Customers for the benefits provided by Islamic bank to Customers, namely in the form of benefit leasing services provided in the form of a sum of money. While the wakalah contract is carried out in the form of a power of attorney from the Islamic bank to the Customer to pay the amount of money to the owner of the item to be rented. So in principle, the wakalah contract is carried out first so that the Islamic Bank controls the goods being rented. Only after the goods are controlled by the Islamic bank, the ijarah contract 
Kamalia Firdausi: Study Of Contract Object In Multi-Service Financing Using Ijarah In...

between the Islamic bank and the Customer is born.

In the ijarah contract between the Islamic bank and the customer, it is known that the Islamic bank rents out the shop to the customer after in principle the shop has been rented by the Islamic bank. Based on the DSN-MUI Fatwa Number 112/DSN-MUI/IX/2017, musta'jir in the ijarah ala al-a'yan contract may lease it back to another party unless it is not permitted by mu'jir. It means, Islamic banks as musta'jir or tenants can lease back to customers unless prohibited by shop owners as $m u$ 'jir.

To find out whether mu'jir gives permission to musta'jir to rent back goods to another party is basically seen from the lease agreement between mu'jir and musta'jir, either verbally or in writing. But in practice, Islamic banks as musta'jir do not act directly to rent goods to $m u^{\prime} j i r$, but rather by empowering customers to rent to mu'jir on behalf of Islamic banks using a wakalah contract. So, Islamic banks do not know for sure whether the owner of the goods allows to rent back the goods or not. Islamic banks only assume that the owner of the goods allows to rent back the goods to other parties, so that an ijarah contract occurs between the Islamic bank and the customer.

Seeing what happens in the ijarah contract between the Islamic bank and the customer, it can be seen that there is a possibility of gharar. Gharar in question is gharar in terms of the contract object (Mubarok \& Hasanudin, 2017), in which Islamic banks lease out stores that is not its ownership to customers only on the assumption that the shop owner gives permission to be able to re-rent the shop to other parties without knowing for sure whether the shop owner is right-has given permission.

\section{CONCLUSION}

In the quo case decision, the Panel of Judges decided to reject all claims of the Plaintiff (Customer), so that the Plaintiff's claim regarding the cancellation of the contract on multi-service financing related to the contract object was also rejected by the Panel of Judges. In its legal considerations, the Panel rejected the Plaintiff's claim because in the trial the Plaintiff could not prove the arguments for the lawsuit which stated that the contract object in the contract was not an object that could be used as the object of the ijarah contract, so according to the Panel of Judges the Plaintiff's claim should have been rejected. According to the author, the judges' legal considerations in the decision were only guided by the procedural law. Even though in the contract there is still the possibility of gharar in terms of the contract object. If in a contract there is gharar, then the contract is included in the fasid contract or contract that is invalid. Regarding the fasid contract, the majority of scholars agreed that the contract had no form and had no legal consequences. In other words, such a contract is deemed never to have existed or is null and void by law. Therefore, the legal considerations of the Panel of Judges in the decision did not reflect 
sharia principles because the Plaintiff's claim regarding the cancellation of the contract on multi-service financing related to the contract object should have been accepted by the Panel of Judges.

\section{REFERENCSES}

Abu Azam Al Hadi. (2017). Fikih Muamalah Kontemporer. Depok: Rajawali Pers.

Agus Purwanto. (2017). Analisis Hukum Islam terhadap Akad Ijarah pada Pembiayaan Multiguna Tanpa Agunan di Koperasi Jasa Keuangan Syariah (KJKS) BMT Bee Mass Ngawi. Jurnal Justisia Ekonomika, Vol. 1(1).

Ahmad Syakur. (2010). Hawalah sebagai Alternatif Pembiayaan Multijasa di Lembaga Keuangan Syariah. Jurnal Muqtasid, Vol. 1(2), 345-364.

Ajeng Mar'atus Solihah. (2014). Penerapan Akad Ijarah pada Pembiayaan Multijasa dalam Perspektif Hukum Islam. Az Zarqa', Vol. 6(1), 103-121.

Akad Pembiayaan Ijarah Multijasa No. 374/IJR/DS/01/2016.

Akad Transaksi Wakalah No. 374/WK/IJR/DS/01/2016.

Akhmad Farroh Hasan. (2018). Fiqh Muammalah dari Klasik hingga Kontemporer (Teori dan Praktik). Malang: UIN-Maliki Malang Press.

Andzari Nurkamilah, Titin Suprihatin, \& Eva Misfah Bayuni. (2016). Analisis Fatwa DSN tentang Pelaksanaan Akad Ijarah pada Pembiayaan BMT Itqan Bandung. Prosiding Keuangan dan
Perbankan Syariah, Vol. 2(2), 615623.

Annisa Eka Rahayu, \& Neneng Nurhasanah. (2020). Konstruksi Akad Ijarah pada Fatwa DSN-MUI tentang Pembiayaan Multijasa. Laa Maisyir: Jurnal Ekonomi Islam, Vol. 7(1), 86-102.

Eny Latifah, \& Cindy Andini Fariskasari. (2020). Relevansi Penerapan Produk Multijasa pada Islamic Microfinance Institutions dengan Kesejahteraan Masyarakat. $A l$ Manhaj: Jurnal Hukum dan Pranata Sosial, Vol. 2(2), 216-237.

Fatwa Dewan Syariah Nasional Majelis Ulama Indonesia No. 09/DSNMUI/IV/2000 tentang Pembiayaan Ijarah.

Fatwa Dewan Syariah Nasional Majelis Ulama Indonesia No. 44/DSNMUI/VIII/2004 tentang Pembiayaan Multijasa.

Fatwa Dewan Syariah Nasional Majelis Ulama Indonesia No. 112/DSNMUI/IX/2017 tentang Akad Ijarah.

Husain Insawan. (2017). Al-Ijarah dalam Perspektif Hadis; Kajian Hadis dengan Metode Maudhu'iy. Li Falah: Jurnal Studi Ekonomi dan Bisnis Islam, Vol. 2(1), 137-154.

Jaih Mubarok, \& Hasanudin. (2017). Fikih Mu'amalah Maliyah: PrinsipPrinsip Perjanjian. Bandung: Simbiosa Rekatama Media.

Jaih Mubarok, \& Hasanudin. (2017). Fikih Mu'amalah Maliyyah: Akad Ijarah dan Ju'alah. Bandung: Simbiosa Rekatama Media. 
Kamalia Firdausi: Study Of Contract Object In Multi-Service Financing Using Ijarah In...

Mahfudzotin Nikmah, Hari Sutra Disemadi, \& Ani Purwanti. (2020). Akibat Hukum Perjanjian Jual Beli Rumah Melalui Kredit Pemilikan Rumah secara Over Credit di Bawah Tangan. Jurnal Cendekia Hukum, Vol. 6(1), 13-28.

Mardhiyah Hayati. (2014). Pembiayaan Ijarah Multijasa sebagai Alternatif Sumber Pembiayaan Pendidikan (Kajian terhadap Fatwa Dewan Syariah Nasional No. 44/DSNMUI/VIII/2004 tentang Pembiayaan Multijasa. ASAS, Vol. 6(2), 78-86.

Muhammad Ardi. (2016). Asas-Asas Perjanjian (Akad), Hukum Kontrak Syariah dalam Penerapan Salam dan Istisna. Jurnal Hukum Diktum, Vol. 14(2), 265-280.

Muhammad Syafi'i Antonio. (2001). Bank Syariah: Dari Teori ke Praktek. Jakarta: Gema Insani.

Mukti Fajar ND, \& Yulianto Achmad. (2010). Dualisme Penelitian Hukum. Yogyakarta: Pustaka Pelajar.

Mulya Lazwardi. (2018). Wanprestasi dalam Akad Pembiayaan Ijarah Multijasa (Analisi Putusan Pengadilan Agama Purbalingga No. 1721/Pdt.G/2013/PA.Pbg).

RechtIdee, Vol. 13(2), 139-159.

Nurul Khasanah, \& Muhamad Mustaqim. (2020). Relevansi Fatwa DSN-MUI pada Praktik Akad Ijarah Pembiayaan Multijasa. Islamiconomic: Jurnal Ekonomi Islam, Vol. 11(1), 93-108.

Otoritas Jasa Keuangan. (2015). Kodifikasi Produk dan Aktivitas
Standar Bank Umum Syariah dan Unit Usaha Syariah. Jakarta: Otoritas Jasa Keuangan.

Otoritas Jasa Keuangan, Departemen Ekonomi dan Keuangan Syariah Bank Indonesia, \& Direktorat Pembiayaan Syariah Ditjen Pengelolaan Pembiayaan dan Risiko Kemenkeu. (2017). Laporan Perkembangan Keuangan Syariah Indonesia 2017. Jakarta: Otoritas Jasa Keuangan.

Roifatus Syauqoti, \& Mohammad Ghozali. (2018). Kesesuaian Fatwa DSN/MUI No. 44/DSNMUI/VIII/2004 dengan Akad Ijarah Multijasa (Studi Kasus di BMT HIRA Cabang Tanon). Jurnal Ijtihad, Vol. 12(1), 1-19.

Salim HS, \& Muhaimin. (2018). Teknik Pembuatan Akta Akad Pembiayaan Syariah (Materi Kuliah TPA Dua). Depok: Rajawali Pers.

Silvia Nur Febrianasari. (2020). Hukum Ekonomi Islam dalam Akad Ijarah dan Rahn. Jurnal Qawanin, Vol. 4(2), 193-208.

Sri Sudiarti. (2018). Fiqh Muamalah Kontemporer. Medan: FEBI UINSU Press.

Syamsul Anwar. (2007). Hukum Perjanjian Syariah Studi tentang Teori Akad dalam Fikih Muamalat. Jakarta: PT RajaGrafindo Persada.

Taqiyuddin an Nabhani. (2009). Sistem Ekonomi Islam. Bogor: Al-Azhar Press2.

Winda Ika Pratiwi, \& Moch Novi Rifa'i. (2017). Implementasi Akad Murabahah dan Ijarah Muntahiyah 
Jurnal Cendekia Hukum: Vol. 6, No 2, Maret 2021

Bit Tamlik Pada Produk KPR BRI Syariah KC Malang Kawi. Falah: Jurnal EKonomi Syariah, Vol. 2(2), 156-176. 